\title{
清水展 著
}

\section{『草の根グローバリゼーション 世界遺産棚田村の文化実践と生活戦略』}

京都大学学術出版会 2013年 vi +468頁

\section{葉山 アッコ}

本書は，世界を同質化し，地域の個別性を消し去るかのように進展するグローバル 化が，むしろそのような力に反発し対抗する力を地域にもたらし，それが新たな社会 編成のための活路を切り開くということ, そしてそのような新しい潮流を開発途上国 の辺境の地に生きる貧しく小さな人々が主導しているということを見出した書である。 本書が描く，新たな社会関係構築の可能性を示す「辺境からのグローバル化」ある いは「草の根からのグローバル化」の企ての場は, フィリピンのなかでも辺境の地で ある北ルソンの山奥の小さな村，イフガオ州フンドゥアン郡ハパオ村である。

この民族誌が極めて優れた作品であるのは，本書が描く，スペイン，アメリカ，日 本の侵入というグローバル・パワーと対峙した 500 年間のとてつもなく長く，そして NGO 同士のつながりを通して交流するようになった兵庫県丹波の山間の町のみなら ず，ここ20年で急増した村からの海外出稼ぎ者の30力国近い渡航先までをも含むとて つもなく広い, 時間的, 空間的広がりのなかにこの辺境の局所を位置づけ, グローバ ル化の捉え直しを私たちに問うているからだけではない。文化人類学者である著者が, 研究対象である人々が自らの文化をめぐって他の人々と行う交渉や事態の成り行きに, 自ら進んで巻き込まれ参与しようとする人類学，「コミットメントの人類学」(第 4 章) の可能性に挑戦した書でもあるからである。グローバル化の進展のなかで辺境に住む 人々が，自らの歴史や文化を自覚し，アイデンティティを強化し，そのために文化を 資源化し，そして意味を付与するという一連の実践において，本書が具体的に描くの は，森林減少という環境問題，それへの対応としての植林事業，そして生計向上のた めの開発援助問題という極女て今日的な課題である。

本書は，序章にあたる第 1 章と 4 部に分けられた本文（第 2 章から第10章）から 成り立つている。第 1 部「地域と世界を結びなおす企て」には，グローバル化の波に 対峙, 便乗し, 雄弁に自己表現する二人のネイティブ知識人が登場し，フィリピンの 
原住民イフガオの文化を称揚し積極的に資源化する彼らの企てが説明される。一人は， イフガオであることの民族的自覚を強化するという目的をもって，植林事業を住民の 自発性と自助努力に基づく運動とするべく，1998年に NPO「イフガオグローバル森 林都市運動」を設立したロペス・ナウヤック氏（1938年生）であり，もう一人は，ナ ウヤック氏を「導師（グル）」「魂のきょうだい」と考える世界的に著名な映画監督キ ッドラット・タヒミック氏（1942年生）である。ナウヤック氏は，過去を未来へと反 転させ，ローカルをグローバルなネットワークに開いてゆくための企てとして植林運 動に意味を付与する。彼は，植林を村人に説得する際には，経済的理由とともにイフ ガオとしてのアイデンティティを支える基盤である森と棚田，それらを造り守り引き 継いできた祖先との絆を強調する。日本に資金援助を要請する際には，イフガオが山 下奉文将軍率いる日本軍主力部隊約 6 万人の逃げ込み地であり，日本兵の食糧強奪 が多くの村人の命を奪ったこと, 山下将軍が降伏したフンドゥアン郡ナプラワン山は 戦争を平和に反転させた地であることを強調する (第 2 章)。

一方，バギオの裕福なエリート家庭に生まれ，フィリピン大学卒業後にアメリカで MBA を取得しパリで国際公務員の職を得た夕ヒミック氏は，英語によるアメリカ式 教育を喜しで身につけ自己形成した自己を解体し，再構築し，自らの精神と身体を真 のフィリピン人として作り直そう，つまり「魂の脱植民地化」(101頁）を果たそうと している。タヒミック氏が，脱植民地化の思想や運動を主導する他の知識人と大きく 異なるのは，氏が，フィリピン社会のマジョリティである平地キリスト教民からは遅 れて劣った人々とみなされてきたイフガオをはじめとする北ルソンの山地民の感性と 世界観に脱植民地化の導きを求名いることである。それは，外来勢力の支配と抑圧 に抵抗してきた山地民だけが土着固有の文化とフィリピン人としての根源的なアイデ ンティティを保持し，それがグローバル化の波（アメリカの文化へゲモニーの浸透） に対抗して踏みとどまる力になると考えているからである。イフガオ文化と世界観を 修得するために母親の知り合いであったナウヤック氏の弟子となり, 芸術文化運動の 同志，同伴者として氏に関するドキュメンタリー作品をいくつも製作している。手持 ちの資金で出来ることをするというタヒミック氏の映画製作の基本姿勢は，他人の資 金に頼るために資金の出資者が本当の監督になってしまい，時間の制約に縛られる八 リウッド式映画製作に対する意図的なアンチテーゼになっている。氏の作品は，一見 無手勝流のブリコラージュであるが，それが西欧のエスノセントリズムとそれを支え る枠組み自体に異議を唱え，摇さぶりをかけていく極めて有効な文化戦略になってい る (第 3 章，第 4 章)。こうしてみると，タヒミック氏の企てと生活実践に強く共感 する著者が，氏を通して知り合ったナウヤック氏の同伴者として植林運動に巻き込ま れ，積極的に関与していったのは，必然であったことがよくわかる。 
第 2 部「グローバリゼーションと対峙した500年」では，イフガオが時のグローバ ル大の勢力とそれに対抗する勢力とが焦点化して出現する接触面であり続けたことが 示される。首都マニラから遠く，アクセスが困難な山奥の地であるがゆえに，イフガ 才は西欧近代の主流の考え方や社会の作り方を相対化してゆくためのアイディアや世 界観を得る場として多くの人類学者を惹きつけ，さらに中央政府への反撃力を蓄える ために1970年代後半から20年間，この地域を実効支配した共産党ゲリラを惹きつけ た場であつた (第 5 章)。イフガオと外部社会とのつながりはスペイン来航以前から あったが，植民地期以降のイフガオはスペイン (平定作戦), アメリカ (懐柔策), そ して日本軍 (退却侵入) と対峙し，抵抗し，換骨奪胎して飼い慣らしてきた，グロー バル大のパワーと接触してきた場であった（第 6 章）。

第 3 部「グローバリゼーションを飼い慣らす」では，1990年代に生じた自然環境， 社会経済的環境，人々の意識の変化が描かれる。それらは，森の縮小とそれに歯止 めをかけるためのナウヤック氏による NPO の設立，共産党ゲリラの実効支配終了， 海外出稼ぎによる現金獲得機会の拡大，それと呼応して強化されるようになった伝統 文化への関心とイフガオであることの自覚と伝統儀礼の復活である。棚田と一体にな ってエコ・システムを構成する森（棚田近くの私有林と上部に広がる共有林）は, 現 金収入源である木彫りや家屋建築用木材の伐採で1990年代に急速に縮小していつた。 それを憂慮した当時バギオ在住のナウヤック氏（長年木彫り職人として森の恵みを受 けてきた）が，1997年に一人生まれ故郷のハパオ村に移住し，植林運動を開始した。 開始当初，村人たちは手弁当で協力した。共同で育てた苗を各自が各々の私有林地 に植林し, 植林後の管理も行つた (第 7 章)。村からの海外出稼ぎの急増に伴つて, 個人と民族のアイデンティティとしてイフガオであることの自覚が強化されるように なつた。その覚醒を可視化し確認するためにイフガオの各郡で郡主導による伝統儀礼 (フンドゥアン郡ではトゥゴ祭) がスペクタクル化（伝統衣装を身につけた村ごとの パレードなど）を伴って復活している(第 8 章)。

第 4 部「草の根のグローバリゼーション」では, 著者の, 「コミットメントの人類 学」の実践の果実としての植林運動に対する助成金獲得, フィリピンと日本の人的交 流, そしてそれらがもたらした影響が描かれる。著者が結びつけた国境を隔てた山奥 の NGO 同士の協力は，2001年からの 7 年間に JICA を含む五つの団体から総額8500 万円に達する助成金をもたらした。植林事業面積は，400へクタールに及ぶ。計画通 りに大規模面積を植林するために，手弁当による植林では間に合わず村人に日当を払 うことになった。その結果, 共有地に植えられた苗木を無償労働で管理することがな くなり, 半分近くの苗木が枯れてしまった。一方で, 国境を越えた二つの山奥の村・ 町同士の交流が活発になり，とくに日本の若者たちが長期にわたつて村人と一緒にな 
つて活動したことは，日本兵のイメージと結びつけられていた日本と日本人のイメー ジを良いものに変えた (第 9 章)。

タヒミック氏を介して著者がナウヤック氏に出会ったのが1997年。この小さな出会 いが草の根のグローバル化の企ての一つとして大きく展開していく様は，小さな一粒 の種が大木に育っていくような希望の名にふさわしい伸展である。一方で，わたしに は心配の種が生まれたような気がかりも残る。それは，わたしの研究対象である植林 事業に関することである。

森林再生を重要政策課題とするフィリピンの国有林地では1970年代から住民参加 型の植林事業が展開されてきた。ほとんどが援助機関主導によるものである。そして ほとんど全てにおいて援助終了とともに住民の植林活動も終わった。住民が主導して 植林をする事例は，多くはないがある。しかし，植林運動を，文化的覚醒のための実 践と考え，住民自ら働きかけてグローバルに外部資金を動員した事例は，このナウヤ ック氏の植林運動以外にはないだうう。

そのような文化実践としての植林事業が，結局は，フィリピンの他地域で展開した 住民参加型の大規模植林事業と同じ失敗（植林後の管理不足による高い枯死率）に 終わったことをどう考えたらいいのだううか？ 日本側 NGO はその理由を時間不足 と総括し，NGO が直面した困難と努力を最も理解している著者はそれも止むなしと している。わたしは，そもそも巨額な外部資金を投入して行う大規模植林事業（事業 期間は通常 3 年間）はうまくいかないと考元ている。それは，夕ヒミック氏の映画製 作がアンチテーゼとしている，資金出資者が本当の監督になってしまい時間に制約さ れるハリウッド方式の映画製作と同じ方式の植林スタイルだからである。フィリピン 各地で展開した住民参加型の大規模植林事業の失敗の弊害は，住民に無償労働によ る植林の精神を失わせたことである。イフガオに関してもそれを心配するが，しかし 他地域にはみられない，森と棚田のエコ・システムを民族のアイデンティティの源泉 とし，グローバル化の進展とともに民族の覚醒が強化されているイフガオではこのよ うな心配は杞憂であってほしいと思う。本書に関して強調すべきはこの点ではなく, 辺境の地での草の根のグローバル化がグローバル・パワーによるグローバル化の進展 の対抗勢力になりうるということを示したことにある。そして，それこそが著者の「コ ミットメントの人類学」への挑戦の果実なのである。

（連絡先：hayama_atsuko@kurume-u.ac.jp） 